\title{
STUDI EKSPERIMENTAL PENGARUH KONSENTRASI LUMPUR LAPINDO SEBAGAI PELARUT MIXDESAIN PEMBUATAN BATA RINGAN CELULLAR LIGHTWEIGHT CONCRETE (CLC)
}

\author{
Didik Purwanto ${ }^{(1)}$ dan Agustinus Angkoso ${ }^{(2)}$ \\ ${ }^{1,2}$ Teknik Sipil, Universitas Widya Kartika \\ ${ }^{1,2}$ J1 Sutorejo Prima Utara 2/1, Surabaya, 60116 \\ E-mail : didikitats@gmail.com ${ }^{1)}$, agustinusangkoso@gmail.com ${ }^{2)}$
}

\begin{abstract}
ABSTRAK
Tujuan dari penelitian ini adalah Untuk mengetahui pengaruh penambahan lumpur lapindo terhadap kuat tekan dan densitas serta daya serap air dari bata ringan yang dihasilkan. Selain itu diharapkan bisa diperoleh komposisi pencampuran terbaik dari variabel yang ditetapkan. Hasil dari penelitian dibandingkan dengan standar SNI 03-0349-1989. Pada penelitian ini, Lumpur Lapindo Sidoarjo ini akan digunakan sebagai bahan tambahan dalam pembuatan bata ringan. Kandungan Silika yang ada di dalam Lumpur Lapindo diharapkan mampu meningkatkan kualitas dari Bata ringan jenis cellular lightwieght concrete (CLC). Selain untuk meningkatkan kualitas bata ringan, pemakaian lumpur Lapindo ini diharapkan bisa membantu usaha pemerintah daerah untuk mengurangi volume lumpur yang ada di Sidoarjo. Pembuatan Bata Ringan dilakukan dengan kapasitas $40 \mathrm{~kg} /$ bacth dengan komposisi lumpur lapindo divariasikan sebesar 25\%, 30\% ; 35\% ; 40\%; $45 \%$. Foaming agent ditambahkan sebagai pembentuk busa di dalam mixdesain. Hasil penelitian menunjukkan bahwa penambahan konsentrasi lumpur lapindo membuat densitas bata ringan semakin meningkat. Densitas bata ringan terendah diperoleh pada konsentrasi lumpur lapindo $30 \%$, yaitu senilai $0,92 \mathrm{Kg} / \mathrm{M}^{3}$. Sedangkan densitas tertinggi diperoleh pada konsentrasi lumpur lapindo $45 \%$, yaitu sebesar $1,46 \mathrm{Kg} / \mathrm{M}^{3}$. Penambahan konsentrasi lumpur lapindo juga menyebabkan peningkatan kuat tekan bata ringan. Kuat tekan tertinggi diperoleh pada konsentrasi lumpur $40 \%$ yaitu senilai $128 \mathrm{MPa}$. Berdasarkan hasil tersebut, bata ringan hasil penelitian telah sesuai dengan standar SNI 03-0349-1989.
\end{abstract}

Kata Kunci: Lumpur Lapindo, Bata Ringan, Kuat tekan, CLC, Concrete,

\section{PENDAHULUAN}

Teknologi bata ringan saat ini sedang berkembang pesat terutama setelah banyaknya terjadi gempa di beberapa tempat Indonesia terutama gempa yang pernah mengguncang daerah Lombok, Nusa Tenggara Barat. Pendekatan rancang bangun untuk bangunan tahan gempa harus didasarkan kekuatan lateral, mampu bentuk dan keuletan struktur dengan batas tertentu tetapi tidak mudah runtuh. Faktor utama untuk membuat bangunan tahan gempa yaitu desain bangunan yang aman dan konstruksi dengan material yang berkualitas (Lumingkewas, 2018).

Bata ringan dikenal ada 2 (dua) jenis: Autoclaved Aerated Concrete (AAC) dan Cellular Lightweight Concrete (CLC) (Magwood, 2014). Keduanya didasarkan pada gagasan yang sama yaitu menambahkan gelembung udara ke dalam mortar akan mengurangi berat bata yang dihasilkan secara drastis. Perbedaan bata ringan AAC dengan CLC adalah dari segi proses pengeringan yaitu AAC mengalami pengeringan dalam oven autoklaf bertekanan tinggi sedangkan bata ringan jenis CLC yang mengalami proses pengeringan alami. CLC sering disebut juga sebagai Non-Autoclaved Aerated Concrete (NAAC) (Thakur, 2015). Bata ringan CLC merupakan bata ringan yang mengalami proses curing secara alami, yang mana agregat kasar (kerikil) diganti dengan gelembung udara, dalam prosesnya menggunakan busa organik yang kurang stabil dan tidak ada reaksi kimia ketika proses pencampuran adonan, foam/busa berfungsi hanya sebagai media untuk membungkus udara. Pabrikasi dan peralatan yang digunakan untuk menghasilkan CLC juga standar, sehingga produksi dengan mudah dapat pula diintegrasikan ke dalam pabrikasi beton konvensional. Pemakaian foam agent dalam campuran berfungsi untuk memerangkap void pada mortar, sehingga didapat bobot isi kering (dry density) antara $500 \mathrm{~kg} / \mathrm{m}^{3}-1600 \mathrm{~kg} / \mathrm{m}^{3}$ (Abdul, M., dkk, 2018; Rahmawati \& Meliyana, 2019; Trinugroho \& Murtono, 2015)

Sedangkan standar SNI untuk pengujian bata ringan dan ASTM sebagai acuan spesifikasi bahan penyusun bata ringan. Mix design mengacu pada massa jenis bata ringan berdasarkan standar SNI 2847-2013 yaitu massa jenisnya antara $1.140 \mathrm{~kg} / \mathrm{m} 3$ sampai dengan $1.840 \mathrm{~kg} / \mathrm{m}^{3}$ (Widyawati \& Aqqi, 2020; Medriosa \& Fantoni, 2020)

Banjir Lumpur Panas Sidoarjo ialah peristiwa menyemburnya lumpur panas di lokasi pengeboran Lapindo Brantas Inc di Dusun Balongnongo Desa Renokenongo, Kecamatan Porong, Kabupaten Sidoarjo, Jawa Timur sejak tanggal 29 Mei 2006 (Pusat Data dan Analisa TEMPO, 2019). Semburan lumpur panas ini 
telah menyebabkan tergenangnya kawasan pemukiman, pertanian, dan perindustrian di tiga kecamatan di sekitarnya, serta mempengaruhi aktivitas perekonomian di Jawa Timur (Dewantara, 2013)

Saat ini semburan lumpur masih berlangsung dengan kapasitas sebesar $30.000 \mathrm{~m}^{3}$ sampai dengan $80.000 \mathrm{~m}^{3}$ per hari dengan suhu di pusat semburan $>100^{\circ} \mathrm{C}$, hal ini disebabkan masih tingginya tekanan dari dalam bumi sehingga masih memerlukan penanganan dan pengendalian yang lebih baik (Lasino \& Setiati, 2017)

Hasil analisis kimia dari lumpur Sidoarjo yang dilakukan oleh Lasino \& Setiati (2017) menunjukkan bahwa senyawa $\mathrm{SiO}_{2}$ adalah yang paling dominan di dalam lumpur Sidoarjo. Jumlah presentasi rata-rata senyawa tersebut adalah 51,92 \%. Urutan kedua adalah $\mathrm{Al}_{2} \mathrm{O}_{3}$ sebesar 25,07\% dan $\mathrm{Fe}_{2} \mathrm{O}_{3}$ sebesar 8,53\%. Senyawa terkecil yang terdapat dalam lumpur Sidoarjo adalah $\mathrm{SO}_{3}$ dengan jumlah rata-rata sebanyak 0,96\%. Kandungan $\mathrm{Si}$ yang berlimpah tersebut membuat lumpur Sidoarjo dapat berpotensi sebagai bahan mentah untuk material pozzolan, seperti halnya fly ash (Dibiantara, dkk, 2014).

Penelitian lainnya oleh Abi, dkk (2014) telah berhasil membuat bata ringan dengan campuran lumpur lapindo. namun masih membutuhkan energi tinggi karena lumpur terlebih dahulu diolah dengan pemanasan pada suhu tinggi untuk mendapatkan silika murni.

Pada penelitian dengan pemanfaatan bahan limbah lainnya dimana Bata dibuat dengan penambahan limbah plastik PET dan serat sisal. Bata yang dihasilkan memiliki massa jenis rata-rata $1830,419 \mathrm{~kg} / \mathrm{m}^{3}$ untuk sampel bata 1:1 yang termasuk dalam kategori bata ringan. Dikatakan bahwa penggunaan limbah plastik PET dapat menjadi penambah agregat kasar dalam pembuatan bata ringan sedangkan penambahan serat sisal memberikan pengaruh yang baik untuk kekuatan bata sehingga bata tidak mudah pecah saat pengujian tekan (Widyawati \& Aqqi, 2020).

Pada penelitian ini, Lumpur Lapindo Sidoarjo digunakan sebagai bahan tambahan pengurang pasir dimana kandungan Silika yang ada di dalam Lumpur Lapindo diharapkan mampu meningkatkan kualitas dari Bata ringan jenis Cellular Lightwieght Concrete (CLC). Untuk menghindari pemanasan berlebih, pada penelitian ini Lumpur Lapindo akan divariasikan konsentrasinya dan dicampurkan ke air sebagai pelarutnya.

Hasil bata ringan dengan melibatkan pelarut lumpur lapindo akan dibandingkan dengan kualitas bata ringan dari proses produksi dengan mix desain standar menggunakan pelarut air. Jadi tujuan Penelitian Dosen Pemula ini adalah peningkatan kualitas dari produk Bata ringan jenis CLC dengan pemanfaatan lumpur lapindo sidoarjo (bahan alam lokal) yang divariasikan konsentrasinya

\section{RUANG LINGKUP}

Dalam penelitian ini permasalahan mencakup:
1. Apakah penambahan larutan lumpur lapindo secara langsung dala mix desain Bata ringan mampu meningkatkan kekuatan dari Bata Ringan

2. Bagaimanakah komposisi yang tepat untuk menghasilkan bata ringan yang lebih kuat dan ringan Sedangkan batasan masalah dalam penelitian ini.

1. Kekuatan Bata ringan hanya ditinjau dari pengujian kuat tekan berdasarkan ASTM C39-11

2. Pembandingan hasil bata ringan dilakukan dengan standar nasional Indonesia bata ringan yaitu berdasarkan standar SNI 2847-2013

\section{BAHAN DAN METODE}

Pada penelitian ini dibuat specimen bata ringan dengan ukuran $20 \times 7,5 \times 60 \mathrm{~cm}$. Untuk pengujian specimen dilakukan tes kuat tekan berdasarkan ASTM C39-11.

\subsection{Material yang digunakan}

Dalam material yang digunakan mencakup:

1. Lumpur Lapindo Sidoarjo

Lumpur lapindo diambil langsung dari lokasi yang berjarak $500 \mathrm{~m}$ dari pusat semburan. Melalui bantuan paguyupan masyarakat sekitar, peneliti mendapatkan lumpur lapindo dalam bentuk pasta berwarna kehitaman seperti tanah liat yang berpasir halus. Lumpur tersebut diencerkan dengan air yang komposisinya sudah ditetapkan dalam mixdesain. Konsentrasi lumpur lapindo terhadap air total divariasikan mulai $25 \%, 30 \%, 35 \%, 40 \%$, dan $45 \%$.

2. Semen Portland tipe 1

Semen diperoleh dari toko bangunan terdekat. Berdasarkan percobaan yang telah dilakukan, didapat berat jenis semen sebesar $3.07 \mathrm{gram} / \mathrm{cm}^{3}$.

3. Bahan Pengembang Busa

Bahan pengembang busa atau disebut juga Foaming agent dibeli secara online dimana diperoleh foaming agent dengan merk Meycofix SLF. Penyusun utama dari Meycofix SLF 20 adalah alkohol dan sulphuric ester, berbentuk cairan dengan warna kuning pucat cenderung bening. Foam ini memiliki tingkat keasaman atau $\mathrm{pH}$ antara 6.5 hingga 8.

4. Pasir lokal

Pasir diperoleh dari toko bangunan terdekat dan diayak halus untuk memperoleh ukuran yang homogen. Jumlah pasir menyesuaikan dengan penambahan lumpur lapindo.

Secara keseluruhan, mix desain bata ringan dibuat seperti pada tabel 1 .

Tabel 1. mixdesain bata ringan penelitian

\begin{tabular}{|c|c|c|c|c|c|}
\hline $\begin{array}{c}\% \\
\text { lumpur }\end{array}$ & $\begin{array}{c}\text { kod } \\
\mathrm{e}\end{array}$ & $\begin{array}{c}\text { Semen } \\
(\mathrm{kg})\end{array}$ & $\begin{array}{c}\text { Pasir } \\
(\mathrm{kg})\end{array}$ & $\begin{array}{c}\text { Lumpur } \\
(\mathrm{kg})\end{array}$ & $\begin{array}{c}\text { Air } \\
(\mathrm{kg})\end{array}$ \\
\hline 25 & $\mathrm{~A}$ & 9 & 19,75 & 2,25 & 9 \\
\hline 30 & $\mathrm{~B}$ & 9 & 19,3 & 2,7 & 9 \\
\hline 35 & $\mathrm{C}$ & 9 & 18,85 & 3,15 & 9 \\
\hline 40 & $\mathrm{D}$ & 9 & 18,4 & 3,6 & 9 \\
\hline 45 & $\mathrm{E}$ & 9 & 17,95 & 4,05 & 9 \\
\hline
\end{tabular}




\subsection{Metode penelitian}

Penelitian dilakukan secara eksperimen. Ditahap awal dilakukan penimbangan seluruh bahan yang dibutuhkan sesuai dengan Mixdesain. Kemudian dilakukan pencampuran pasir dan semen secara manual hingga campuran homogen. Diwadah yang lain, lumpur lapindo diencerkan dengan air sesuai dengan konsentrasi yang diinginkan, lalu diaduk hingga terjadi larutan lumpur. Di wadah yang lain lagi dibuat busa dengan cara mengaduk $300 \mathrm{ml}$ cairan foaming agent berkonsentrasi $10 \%$ dengan mixer yang dibuat dari bor listrik. Busa akan terbentuk hingga volume 30 liter, dapat dilihat pada Gambar 1.

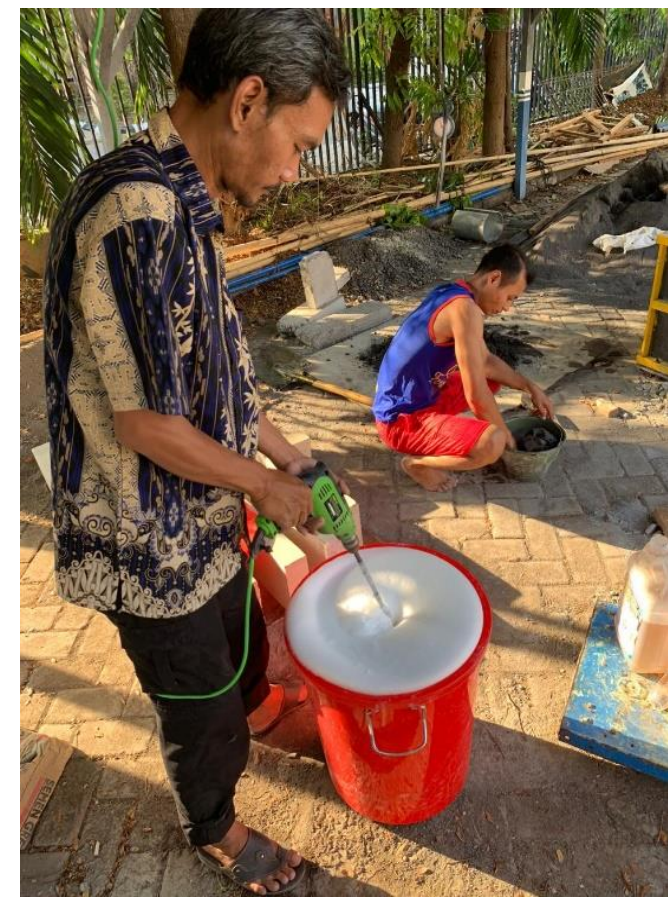

Gambar 1. Proses pembuatan busa

Tahap kedua adalah mencampurkan larutan lumpur lapindo kedalam campuran pasir dan semen, lalu mengaduknya secara manual hingga terjadi adonan berbentuk pasta yang homogen. Kemudian menuangkan adonan lumpur-semen-pasir kedalam busa dan mengadukkan dengan mixer (bor listrik) selama 10 menit.

Ditahap akhir, campuran lumpur-semen-pasir-busa tersebut dituangkan kedalam alat cetak bata ringan dimana sekat-sekatnya terbuat dari fiber dan rangkanya dari besi. Setelah 3 hari, alat cetakan dibongkar dan bata ringan hasil penelitian dikeluarkan. Kemudian bata ringan dijemur di udara terbuka hingga waktunya pengujian, dapat dilihat pada Gambar 2.

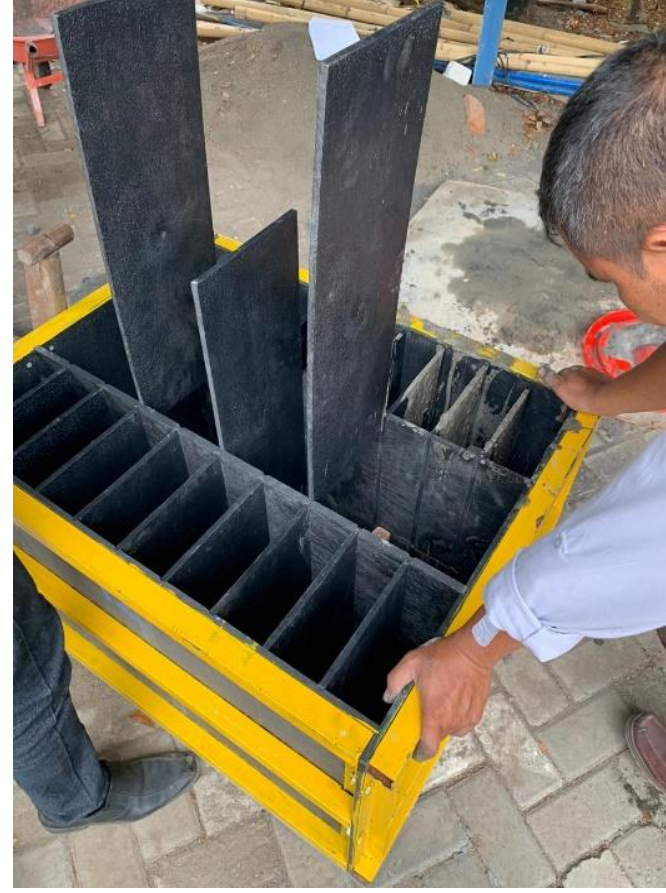

Gambar 2. Alat cetak bata ringan

\subsection{Pengujian Material dan Hasil Penelitian}

Proses penelitian dilakukan seluruhnya di Laboratorium Teknik Sipil Universitas Widya Kartika Surabaya. Sifat mekanik dari spesimen diuji dengan tes kuat tekan (ASTM C 39-03) pada umur 7, 14, 21 dan 28 hari. Pelaksanaan pengujian dilakukan di Laboratorium Teknologi Beton Universitas Narotama Surabaya.

1. Berat volume Benda Uji

Berat Volume adalah pengukuran berat setiap satuan volume benda. Berat volume disebut densitas. Secara sederhana pengukuran berat volume dilakukan melalui penimbangan benda untuk mendapat massa benda. Pengukuran volume benda dengan mencelupkan benda di dalam air sehingga diperoleh volume air yang dipindahkan mewakili volume benda. Maka densitas benda diperoleh dengan membandingkan massa benda dengan volume benda.

2. Kuat Tekan (Compressive Strength)

Untuk mengetahui kekuatan tekan bata ringan dilakukan pengujian kuat tekan. Pada mesin uji tekan benda yang akan diuji diletakkan dan diberikan beban sampai benda retak atau rusak. Beban yang mampu ditahan adalah kuat tekan yang dimiliki oleh benda.

\section{PEMBAHASAN}

Bata ringan hasil dari penelitian dibandingkan dengan kualifikasi bata ringan yang telah distandarkan seperti pada tabel 2 . 
Tabel 2.Persyaratan Fisik Bata Beton menurut SNI 03-0349-1989

\begin{tabular}{|l|l|l|l|l|l|}
\hline Syarat Fisis & Satuan & \multicolumn{4}{|c|}{$\begin{array}{c}\text { Tingkat Mutu Bata } \\
\text { Beton Pejal }\end{array}$} \\
\cline { 3 - 6 } & & I & II & III & IV \\
\hline $\begin{array}{l}\text { Kuat Tekan bruto rata- } \\
\text { rata minimum }\end{array}$ & $\mathrm{Kg} / \mathrm{cm}^{3}$ & 100 & 70 & 40 & 25 \\
\hline $\begin{array}{l}\text { Penyerapan air rata- } \\
\text { rata maksimal }\end{array}$ & $\%$ & 25 & 35 & - & - \\
\hline
\end{tabular}

Secara fisik, Produk bata ringan yang dihasilkan dalam penelitian ini. Bata ringan yang dihasilkan berwarna abu-abu. Semakin lama umur bata ringan, warna bata ringan semakin cerah dan terang. Tekstur bagian permukaan bata ringan halus dan merata. Saat dibelah, bagian dalam terlihat berpori dengan ukuran pori yang bervariasi dan kurang merata. Kurang meratanya pori-pori yang terbentuk di dalam bata ringan ini disebabkan karena kurang homogennya pengadukan saat pencampuran lumpur-semen-pasir-busa. Hal ini juga bisa dikarenakan bentuk cetakan yang vertikal dimana saat proses penuangan, diduga pada bagian bawah campuran lebih pejal karena adanya pengaruh gaya gravitasi. Gaya gravitasi ini mendorong campuran mendesak bagian bawah sehingga gelembung atau busa di bagian bawah semakin sedikit dan berpindah ke bagian yang lebih atas, dapat dilihat pada Gambar 3 .

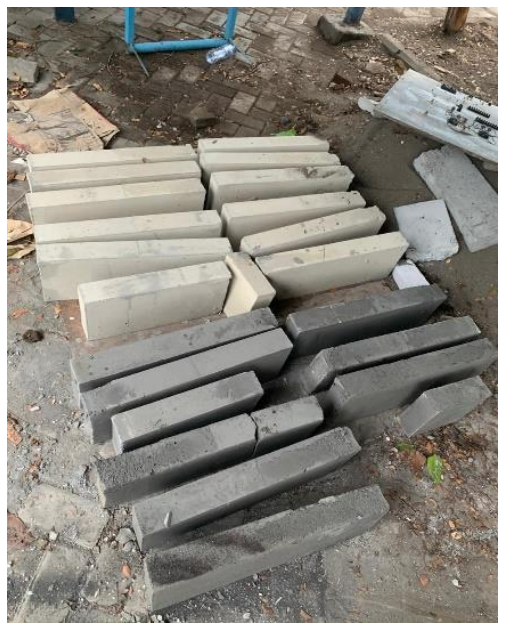

Gambar 3. Gambaran fisik bata ringan hasil penelitian

Berdasarkan hasil pengukuran dan pengujian, bata ringan hasil penelitian mempunyai spesifikasi seperti yang ditunjukkan pada tabel 3 . Indek pengkodean benda uji menunjukkan umur dari dari uji dimana (1) adalah untuk umur benda uji 7 hari, (2) adalah untuk benda uji umur 14 hari, (3) adalah untuk benda uji umur 21 hari, dan (4) adalah untuk benda uji umur 28 hari. Dari tabel 3 tersebut dibuat grafik untuk mengetahui tren pengaruh konsentrasi lumpur lapindo terhadap densitas dan kuat tekan bata ringan.
Tabel 3. Data hasil pengukuran dan pengujian

\begin{tabular}{|l|l|l|l|l|l|}
\hline No & $\begin{array}{l}\text { Nama } \\
\text { beda } \\
\text { uji }\end{array}$ & $\begin{array}{l}\text { Massa } \\
\text { (gr) }\end{array}$ & MPa & Volume & Densitas \\
\hline 1 & A1 & 3506 & 0,9039 & 4425 & 1,0183 \\
\hline 2 & A2 & 4628 & 1,1111 & 4500 & 1,0284 \\
\hline 3 & A3 & 4675 & 1,2444 & 4500 & 1,0388 \\
\hline 4 & A4 & 4651 & 1,9672 & 4575 & 1,0166 \\
\hline 5 & B1 & 4212 & 0,8743 & 4529 & 0,9299 \\
\hline 6 & B2 & 4117 & 1,8978 & 4455 & 0,9241 \\
\hline 7 & B3 & 6302 & 2,9279 & 4440 & 1,4193 \\
\hline 8 & B4 & 6415 & 4,3555 & 4500 & 1,4555 \\
\hline 9 & C1 & 5417 & 1,1299 & 4425 & 1,2241 \\
\hline 10 & C2 & 6035 & 1,6931 & 4725 & 1,2772 \\
\hline 11 & C3 & 6215 & 1,9672 & 4575 & 1,3584 \\
\hline 12 & C4 & 6226 & 3,6781 & 4359 & 1,4312 \\
\hline 13 & D1 & 5697 & 1,8079 & 4425 & 1,2741 \\
\hline 14 & D2 & 5065 & 2,6229 & 4575 & 1,1071 \\
\hline 15 & D3 & 6258 & 4,9717 & 4425 & 1,4142 \\
\hline 16 & D4 & 6375 & 5,5956 & 4575 & 1,3934 \\
\hline 17 & E1 & 6697 & 1,7486 & 4575 & 1,4638 \\
\hline 18 & E2 & 6029 & 3,3333 & 4500 & 1,3387 \\
\hline 19 & E3 & 6469 & 4,6666 & 4500 & 1,4375 \\
\hline 20 & E4 & 6575 & 5,5555 & 4500 & 1,4511 \\
\hline & & & & & \\
\hline
\end{tabular}

Gambar 4 pengaruh variasi konsentrasi lumpur Lapindo dan umur produk terhadap densitas bata ringan hasil penelitian bisa dilihat pada grafik. Bahwa pada masa umur bata 7 - 21 hari densitas bata masih fluktuasi. Hal ini dikarenakan pada umur 7 -21 hari kondisi bata masih belum stabil dan masih terjadi proses pengeringan. Gelembung-gelembung udara yang ada di dalam bata masih ada yang berkurang dan hilang dikarenakan masih ada proses pengerasan dan pemadatan (Adonaranita \& Suryanto, 2014)

Pada dasarnya, bata hasil penelitian diinginkan untuk mempunyai densitas yang lebih rendah. Jika dibandingkan dengan standar SNI, dimana massa jenis bata ringan berdasarkan standar SNI 2847-2013 antara $1.140 \mathrm{~kg} / \mathrm{m}^{3}$ sampai dengan $1.840 \mathrm{~kg} / \mathrm{m}^{3}$ maka densitas bata hasil penelitian sudah memenuhi standar. Nilai densitas di dalam bata ringan dipengaruhi komposisi busa atau gelembung udara yang ada di bata. Jika gelembung udara mampu diciptakan lebih banyak di dalam bata maka densitas akan semakin kecil. Dengan adanya penambahan lumpur lapindo yang mengandung partikel-partikel silika, diduga sebagian rongga-rongga dara yang awalnya terbentuk akhirnya terisi oleh partikel-partikel silika sehingga ata semakin pejal dan densitasnya pun semakin bertambah. Hal ini bisa menjelaskan mengapa semakin besar konsentrasi penambahan lumpur lapindo membuat densitas bata ringan hasil penelitian semakin besar pula. Densitas terendah yang dihasilkan dari penelitian ini adalah 0,92 $\mathrm{kg} / \mathrm{m}^{3}$ yang diperoleh pada konsentrasi Lumpur sebesar $30 \%$ pada umur 14 hari. Sedangkan densitas tertinggi adalah 1,46 yang diperoleh pada konsentrasi lumpur lapindo $45 \%$ pada umur 7 hari. 


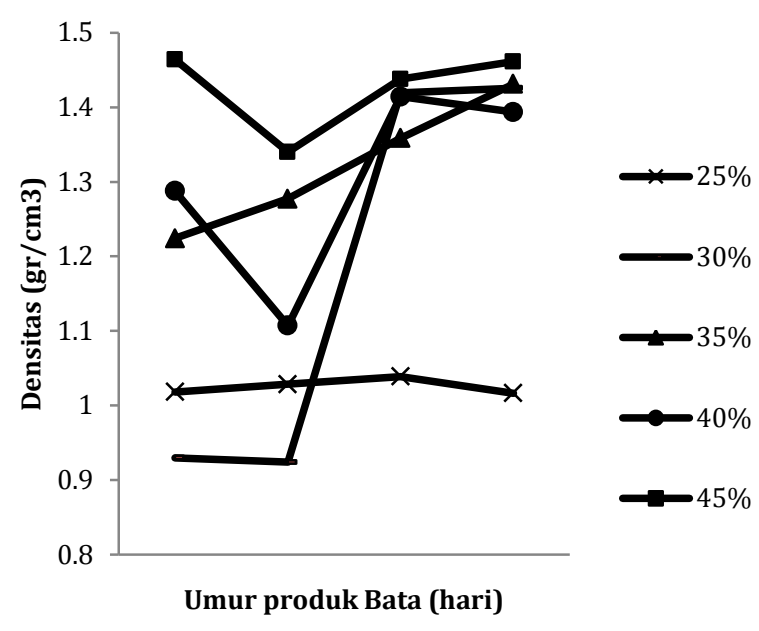

Gambar 4. Grafik tren densitas bata pada berbagai variasi konsentrasi lumpur lapindo

Gambar 5 dari sisi kekuatan bata, produk bata hasil penelitian diuji kuat tekannya dengan peralatan standar ASTM C 39-03. Tren kuat tekan produk bata.

Berdasarkan grafik diatas terlihat bahwa umur pengujian sampel memberikan pengaruh yang signifikan dimana semakin lama waktu pengujian kuat tekan sampel semakin besar. Selain itu, konsentrasi lumpur lapindo memberikan tren positif dimana terlihat bahwa keberadaan lumpur lapindo mampu memberikan penambahan nilai kuat tekan. Pada konsentrasi $40 \%$ dan $45 \%$ memberikan nilai kuat tekan di atas konsentrasi yang lain $(25 \%$ - 30\%). Komposisi utama dari Lumpur Lapindo Sidoarjo adalah $\mathrm{SiO}_{2}, \mathrm{Al}_{2} \mathrm{O}_{3}$ dan $\mathrm{Fe}_{2} \mathrm{O}_{3}$. Kandungan tersebut mampu mempercepat dan mempererat ikatan antara semen dengan pasir dan agregrat lainnya. Eratnya ikatan antar agregat ini didukung dengan semakin membesarnya densitas sampel pada konsentrasi lumpur lapindo yang tinggi.

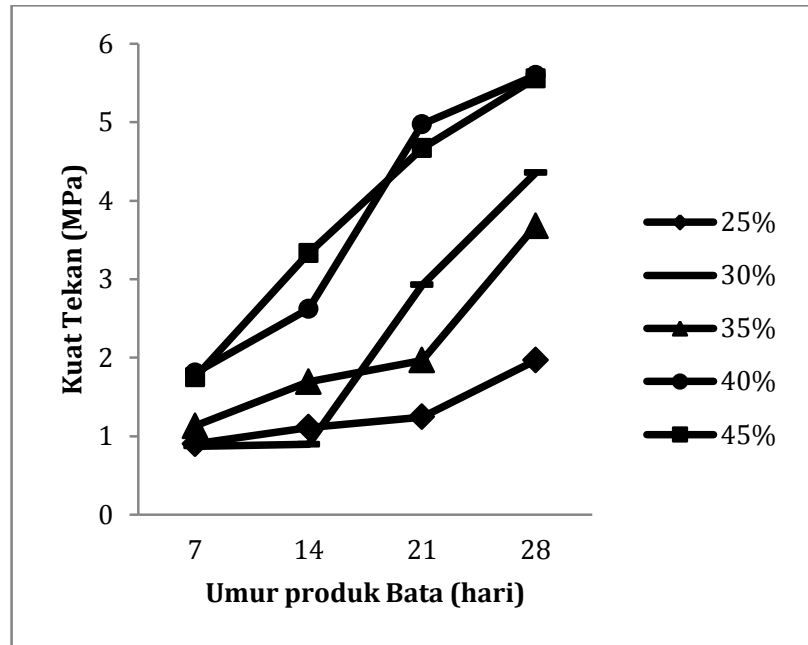

Gambar 5. Grafik tren kuat tekan bata pada berbagai variasi konsentrasi lumpur lapindo
Jika dibandingkan dengan standar Persyaratan Fisik Bata Beton menurut SNI 03-0349-1989, maka bata ringan hasil penelitian bisa dikelompokkan dalam beberapa kategori kualitas. Pada penambahan konsentrasi lumpur lapindo $25 \%$, nilai kuat tekan tertinggi sebesar $45 \mathrm{MPa}$. Nilai kuat tekan tersebut masuk dalam kategori III. Pada penambahan konsentrasi lumpur lapindo $30 \%$ dan $35 \%$ di peroleh kuat tekan tertinggi sebesar $98 \mathrm{MPa}$ dan $80 \mathrm{MPa}$. Nilai kuat tekan ini masuk dalam kategori II. Pada penambahan konsentrasi lumpur lapindo $40 \%$ dan $45 \%$ di peroleh kuat tekan tertinggi sebesar $128 \mathrm{MPa}$ dan $125 \mathrm{MPa}$. Nilai kuat tekan ini masuk dalam kategori I. Dengan nilai kuat tekan yang diperoleh dari pengujian Bata ringan hasil penelitian ini bisa dikatakan seluruhnya telah sesuai dengan standar SNI 03-0349-1989.

Namun jika dihubungkan antara nilai densitas dan kuat tekan bata ringan hasil penelitian, hal ini merupakan dua sisi yang bertolak belakang dari sisi kualitas. Bata ringan diinginkan mempunyai kuat tekan yang tinggi dan densitas yang rendah. Oleh karena perlu diatur lebih rinci mix desain yang bisa mengoptimalkan kuat tekan dan densitas sehingga diperoleh kuat tekan yang tinggi dan densitas yang rendah

\section{KESIMPULAN}

Lumpur lapindo bisa digunakan sebagai bahan alternatif tambahan dalam pembuatan bata ringan. Hasil penelitian menunjukkan bahwa penambahan konsentrasi lumpur lapindo pada range $25 \%$ - $45 \%$ memberikan efek pada penambahan kuat tekan bata ringan, namun juga memberikan dampak membesarnya densitas bata, Jika dibandingkan dengan SNI 03-0349-1989, maka bata ringan yang dihasilkan masuk dalam kualifikasi II -IV. Kuat tekan tertinggi diperoleh pada konsentrasi lumpur $40 \%$ yaitu sebesar $128 \mathrm{MPa}$ sedangkan densitas terendah diperoleh pada konsentrasi lumpur $30 \%$ yaitu senilai adalah $0,92 \mathrm{~kg} / \mathrm{m}^{3}$.

\section{SARAN}

Untuk pengembangan penelitian lebih lanjut, perlu dilakukan treatmen pendahuluan untuk material lumpur lapindo. Di mana kondisi lumpur di lokasi pengambilan material kadang kurang konsisten dan sangat dipengaruhi oleh jarak dari pusat semburan. Proses pembuatan busa juga sebaiknya dilakukan dengan penambahan tekanan dan kecepatan putar pengaduk agar bisa yang dihasilkan lebih banyak dan lebih kuat (stabil). Peralatan cetak bata ringan juga perlu dibuat sedemikian hingga kondisi di semua bagian bata bisa tetap homogen selama proses pengeringan atau pemadatan.

\section{DAFTAR PUSTAKA}

Abdul, M., Abdul, R., \& Raiyyan Rahmi Isda. 2018. Desain Bahan Dasar Campuran Bata Ringan dari Limbah Tambang Emas Pongkor, Jurnal Teknik 
Unjani Vol. 17, No 01, Mei 2018, Hal. 09-18.

Abi, G., Susilo, B., \& Hardjito, D. (2015). Pemanfaatan Lumpur Sidoarjo Pada Pembuatan Bata Ringan Non Struktural Dengan Metode Cellular Lightweight Concrete (Clc). Jurnal Dimensi Pratama Teknik Sipil, 4(2).

Adonaranita, F., \& Suryanto, M. 2014. Pengaruh Komposisi Lumpur Lapindo Sidoarjo terhadap Mutu Batu Bata berdasarkan SNI 15-2094-2000, Jurnal Rekayasa Teknik Sipil.

Dewantara, A. W. (2013). Merefleksikan Hubungan antara Etika Aristotelian dan Bisnis dengan Studi Kasus Lumpur Lapindo. Arete, 2(1), 23-40.

Dibiantara, D. P., Ekaputri, J. J., \& Mohammad, L. M. 2014. Seminar Nasional X - 2014 Teknik Sipil ITS Surabaya, Inovasi Struktur dalam Menunjang Konektivitas Pulau di Indonesia.

Lasino, N., \& Setiati, R. 2017. Pengembangan Lumpur Sidoarjo sebagai Agregat Ringan untuk Beton non Struktural, Jurnal Jalan Jembatan, vol 34 no 2.

Lumingkewas, R. H. 2018. Beton nano komposit serat alam sebagai bahan konstruksi infrastruktur tahan gempa, 251-257.

Magwood, C. (2014). Making Better Buildings: A
Comparative Guide to Sustainable Construction for Homeowners and Contractors. United States: New Society Publishers.

Medriosa, H., \& Fantoni, F. R. 2020. Studi Eksperimen Pengaruh Campuran Sika dalam Meningkatkan Kuat Tekan Bata Ringan. Rang Teknik Journal, 3(1), 1420.

Pusat Data dan Analisa TEMPO. 2019.Lumpur Lapindo Tragedi Sampai Rehabilitasi Wilayah. (n.p.): Tempo Publishing.

Rahmawati, C., \& Meliyana, M. 2019. Potensi Limbah Karbit Sebagai Pengganti Semen Pada Bata Ringan. In Seminar Nasional Multi Disiplin Ilmu Universitas Asahan.

Thakur, M. K. (2015). Chemical Functionalization of Carbon Nanomaterials: Chemistry and Applications. United Kingdom: CRC Press.

Trinugroho, S., \& Murtono, A. 2015. Pemanfaatan Foam Agent dan Material Lokal dalam Pembuatan Bata Ringan. Seminar Nasional Teknik Sipil V 2015

Widyawati, F., \& Aqqi, T. A. 2020. Pemanfaatan Serat Sisal dan Limbah Plastik PET untuk Pembuatan Bata Ringan CLC, Jurnal Tambora Vol 4 no 1 Februari 2020. 